\title{
KUALITAS INTERNAL TELUR AYAM MB 402 YANG DIBERI RANSUM MENGANDUNG MINYAK LIMBAH IKAN CAKALANG (Katsuwonus pelamis $L$ )
}

\author{
Maulana E. Angkow, Jein Rinny Leke*, E. Pudjihastuti, L. Tangkau \\ Fakultas Peternakan. Universitas Sam Ratulangi, Manado
}

\begin{abstract}
ABSTRAK
Tujuan penelitian ini adalah untuk melihat sejauh mana peningkatan kualitas telur ayam MB 402 yang diberikan minyak limbah ikan cakalang (Katsuwonus pelamis $L$ ) dalam ransum, terhadap berat telur, berat kuning telur dan warna kuning telur. Sebanyak 100 ekor ayam petelur MB 402 berumur 36 minggu secara acak dialokasikan untuk 5 perlakuan dengan 5 ulangan. Setiap unit kandang terdiri dari 4 ekor ayam. Perlakuan yang digunakan adalah: ransum basal (R0), ransum basal $99 \%+1 \%$ MLIC (R1), ransum basal $98 \%$ $+2 \%$ MLIC (R2), ransum basal 97\% + 3\% MLIC (R3), ransum basal 96\% + 4\% MLIC (R4). Variabel yang diamati meliputi berat telur, berat kuning telur dan warna kuning telur. Data dianalisis dengan rancangan acak lengkap (RAL). Penambahan minyak limbah ikan cakalang dalam ransum tidak berpengaruh nyata $(\mathrm{P}>0,05)$ terhadap berat telur, berat kuning telur dan warna kuning telur. Berdasarkan hasil penelitian yang dilakukan dapat disimpulkan bahwa penggunaan minyak limbah ikan cakalang dalam ransum sebanyak 4\% memberikan hasil yang sama terhadap kualitas internal telur.
\end{abstract}

Kata kunci : minyak limbah ikan cakalang, ikan cakalang, ayam MB 402, Kualitas internal telur

\footnotetext{
*Korespondensi (corresponding Author)

Email: rinileke@yahoo.com
}

\begin{abstract}
INTERNAL QUALITY OF STRAIN MB 402 LAYING HEN EGG CONSUMING DIETS CONSISTED OF CAKALANG (Skipjack Tuna) FISH OIL WASTE. The purpose of the present study was to determine the inclusion of cakalang (Skipjack tuna) fish oil waste (STO) in the diets on egg weight, egg yolk weight, and egg yellow color. A total of $100 \mathrm{MB} 402$ laying hen aged 36 weeks old were randomly allocated to 5 treatments with 5 replications, each cage unit consisting of 4 chickens. The treatments used were: basal ration without STO (R0), basal feed 99\% + $1 \%$ STO (R1), basal ration $98 \%+2 \%$ STO (R2), basal ration $97 \%+3 \%$ STO (R3), basal ration $96 \%+4 \%$ STO (R4). The variables measured were: egg weight, yolk weight, and egg yolk color. A Completely Randomized Design (CRD) was used as an experimental design. Research results showed that the inclusion of cakalang (Skipjack tuna) fish oil waste (STO) in the diets of MB 402 laying hen did not give a significant $(\mathrm{P}>0.05)$ effect on egg weight, yolk weight, and egg yolk color. It can be concluded that the inclusion of skipjack fish waste in diets up to $4 \%$ has no substantial effect on the internal quality of eggs.
\end{abstract}

Keywords: Cakalang (Skipjack tuna) fish oil waste, MB 402 laying hen, egg internal quality. 


\section{PENDAHULUAN}

Usaha peternakan ayam ras petelur memiliki potensi yang cukup besar untuk dikembangkan sebagai salah satu sumber protein hewani yang dapat memenuhi kebutuhan gizi masyarakat. Sumber protein hewani tersebut diantaranya daging, susu, dan telur. Telur unggas (ayam) mempunyai kandungan asam amino esensial dan non esensial yang cukup lengkap, sehingga sangat cocok untuk memenuhi kebutuhan manusia untuk pertumbuhan, disamping mudah dicerna, mudah didapat, dan murah harganya.

Telur adalah produk peternakan yang kaya gizi dan sangat dibutuhkan oleh tubuh karena merupakan sumber protein, lemak, dan mineral yang murah dan dapat dijangkau oleh samua kalangan masyarakat. Telur merupakan produk peternakan yang memberikan sumbangan besar bagi tercapainya kecukupan gizi masyarakat. Ketersediaan telur yang tidak mengenal musim, keunggulan gizi pada telur dan peningkatan jumlah penduduk di Indonesia yang diikuti dengan tingginya kesadaran masyarakat dalam mengkonsumsi telur, maka hal ini mendorong para perusahaan peternakan untuk meningkatan produk hasil peternakan khususnya produksi telur.

Telur merupakan salah satu jenis pangan hewani utama bagi manusia di seluruh dunia (Gonzales-Esquerra et al., 2000; Milinsk et al., 2003; CarrilloDominguez et al., 2005). Kualitas telur menjadi perhatian penting untuk konsumen. Pada kenyataannya konsumen tidak suka dengan kuning telur yang berwarna pucat dan putih telur yang memiliki bercak merah seperti darah. Warna kuning telur biasanya menentukan telur yang diminati oleh konsumen. Untuk itu, kualitas telur adalah hal penting yang harus diperhatikan dalam memenuhi kebutuhan protein masyarakat. Kualitas telur dapat dilihat antara lain dari haugh unit, warna kuning telur, dan indeks kuning telur. Skor warna kuning telur ayam yang ada di perusahaan peternakan ayam "Dharma Gunawan" berkisar antara $7-8$ berdasarkan roche yolk colour fun.

Minyak limbah ikan cakalang (Katsuwonus pelamis L) yang berasal dari ikan laut merupakan salah satu sumber yang kaya akan asam lemak omega-3 PUFA, selain itu minyak ikan mengandung vitamin $\mathrm{A}$ dan $\mathrm{D}$, pigmen karotenoid, asam lemak Eicosapentanoat (EPA) dan asam dokosaheksanoat (DHA) yang dibutuhkan ayam petelur dalam memproduksi dan pembentukan telur (Hagris et al., 1991; Van Elswyk et al., 1994; Gonzales dan Lesson, 2000).

Minyak ikan di Indonesia pada saat ini belum sepenuhnya merupakan industri yang mandiri. Karena minyak ikan pada 
umumnya diperoleh dari hasil sampingan dari pengolahan ikan kaleng dan tepung ikan. Minyak ikan yang diperoleh dari industri pengalengan pada umunya diperoleh dari bahan mentah yang bermutu tinggi (Permana et al., 2003).

Salah satu cara untuk mendapatkan kualitas internal telur yang bisa diterapkan dalam ransum dengan penggunaan minyak ikan. Minyak limbah ikan cakalang adalah produk samping dari proses yang pemanfaatannya kurang optimal, hanya sebagai limbah pabrik PT Nichindo Manado Suisan, Amurang Minahasa Selatan Privinsi Sulawesi Utara. Pemanfaatan minyak limbah ikan cakalang sebagai pakan ternak terutama unggas petelur dilakukan dengan tujuan untuk mendapatkan kualitas telur yang baik.

Berdasarkan latar belakang yang telah dikemukakan diatas, maka dilakukan penelitian untuk mengetahui sejauh mana kualitas internal telur ayam ras petelur MB 402 yang diberi ransum mengandung minyak limbah ikan cakalang (Katsuwonus pelamis $L$ ) memberikan pengaruh terhadap kualitas internal telur ayam ras.

\section{MATERI DAN METODE PENELITIAN}

\section{Materi Penelitian}

Materi yang digunakan dalam penelitian ini adalah ayam ras petelur fase layer MB 402 berumur 36 minggu, digunakan sebanyak 100 ekor. Pakan yang di berikan terdiri dari jagung kuning, dedak halus, tepung ikan, $\mathrm{CaCO} 3$, konsentrat dan limbah minyak ikan sebagai perlakuan. Kandungan zat makanan bahan pakan dapat dilihat pada Tabel 1, komposisi zat-zat makanan pakan perlakuan pada penelitian ini dapat dilihat pada Tabel 2. Pengamatan dilakukan selama 8 minggu. Kandang battery yang terbuat dari kawat dengan ukuran panjang $60 \mathrm{~cm}$, tinggi bagian depan $35 \mathrm{~cm}$, dan tinggi bagian belakang $30 \mathrm{~cm}$. Secara keseluruhan kandang battery dilengkapi tempat pakan yang dibuat khusus dari bahan pelastik, dan tempat minum yang terbuat dari pipa dibelah menjadi 2 bagian.

\section{Metode Penelitian}

Rancangan percobaan yang digunakan dalam penelitian ini adalah rancangan acak lengkap (RAL) (Steel dan Torrie, 1995). Perlakuan yang digunakan yaitu dengan 5 perlakuan dan 5 ulangan sehingga terdapat 25 unit perlakuan, dimana pada masing-masing unit terdiri dari 4 ekor ayam, sehingga jumlah ayam yang digunakan adalah 100 ekor. Perlakuan disusun berdasarkan iso energy dan protein sesuai dengan perlakuan sebagai berikut :

$$
\begin{aligned}
& \mathrm{R} 0=\text { Ransum Basal } \\
& \mathrm{R} 1=\text { Ransum Basal 99\% }+1 \% \text { MLIC } \\
& \mathrm{R} 2=\text { Ransum Basal 98\% + 2\% MLIC }
\end{aligned}
$$


R3 = Ransum Basal 97\% + 3\% MLIC

Skema pembuatan limbah minyak ikan

R4 = Ransum Basal 96\% + 4\% MLIC dapat dilihat pada gambar 1

Tabel 1. Komposisi Zat-zat dan Bahan Makanan Ransum Makanan

\begin{tabular}{lcccccc}
\hline \multicolumn{1}{c}{ Bahan pakan } & $\begin{array}{c}\text { Protein } \\
(\boldsymbol{\%})\end{array}$ & $\begin{array}{c}\text { SK } \\
(\boldsymbol{\%})\end{array}$ & $\begin{array}{c}\text { Lemak } \\
(\boldsymbol{\%})\end{array}$ & $\begin{array}{c}\text { Ca } \\
(\boldsymbol{\%})\end{array}$ & $\begin{array}{c}\mathbf{P} \\
(\boldsymbol{\%})\end{array}$ & $\begin{array}{c}\text { Energi } \\
\text { Metabolis } \\
(\mathbf{k k a l} / \mathbf{k g})\end{array}$ \\
\hline Jagung kuning $^{1)}$ & 9,42 & 2,15 & 5,17 & 0,22 & 0,6 & 3182 \\
Dedak $^{1)}$ & 12 & 12 & 13 & 0,12 & 0,5 & 1630 \\
Tepung Ikan $^{1)}$ & 60 & 1 & 9 & 5,5 & 0,33 & 2830 \\
$\mathrm{CaCO}_{3}{ }^{2)}$ & 0 & 0 & 0 & 29,4 & 0 & 0 \\
Konsentrat Cal 9.36 $^{2)}$ & 29 & 7 & 10 & 3 & 2 & 2600 \\
$\begin{array}{l}\text { Minyak limbah ikan } \\
\text { cakalang }\end{array}$ & 2,14 & 0 & 20,44 & 0,87 & 0,85 & 6300 \\
\hline Ket: & & & & & &
\end{tabular}

Ket : ${ }^{1)}$ NRC (1994)

2) Sumber PT. Japfa

${ }^{3)}$ Hasil Analisa Laboratorium Nutrisi dan Makanan Ternak.IPB (Leke et al., 2015)

Tabel 2. Komposisi Ransum Perlakuan

\begin{tabular}{lccccc}
\hline \multirow{2}{*}{ Bahan Makanan } & Jagung & Dedak & $\begin{array}{c}\text { KonsentratCal } \\
9,36\end{array}$ & $\begin{array}{c}\text { Tepung } \\
\text { Ikan }\end{array}$ & CaCO3 \\
\cline { 2 - 6 } & \multicolumn{5}{c}{$(\%)$} \\
\cline { 2 - 6 } & 52 & 14 & 24 & 7 & 3 \\
\hline \multirow{2}{*}{ Jenis Bahan Pakan } & \multicolumn{5}{c}{ Jumlah Menurut Perlakuan $(\%)$} \\
\cline { 2 - 6 } & $\mathrm{R} 0$ & $\mathrm{R} 1$ & $\mathrm{R} 2$ & $\mathrm{R} 3$ & $\mathrm{R} 4$ \\
\hline Ransum Basal & 100 & 99 & 98 & 97 & 96 \\
Minyak limbah ikan & 0 & 1 & 2 & 3 & 4 \\
\hline Total & 100 & 100 & 100 & 100 & 100 \\
\hline
\end{tabular}

Tabel 3. Kandungan Zat Makanan Pakan Perlakuan

\begin{tabular}{lccccc}
\hline \multicolumn{1}{c}{$\begin{array}{c}\text { Komposisi Zat-Zat } \\
\text { Makanan }\end{array}$} & \multicolumn{5}{c}{ Persentase (\%) } \\
\cline { 2 - 6 } & $\mathrm{R} 0$ & $\mathrm{R} 1$ & $\mathrm{R} 2$ & $\mathrm{R} 3$ & $\mathrm{R} 4$ \\
\hline Protein & 17,73 & 17,57 & 17,42 & 17,26 & 17,11 \\
Sk & 4,5 & 4,46 & 4,41 & 4,37 & 4,32 \\
Lemak & 6,9 & 7,04 & 7,17 & 7,31 & 7,44 \\
$\mathrm{Ca}$ & 2,33 & 2,32 & 2,30 & 2,29 & 2,27 \\
$\mathrm{P}$ & 0,73 & 0,73 & 0,73 & 0,73 & 0,73 \\
Energi Metabolis (Kkal/kg) & 2704,94 & 2740,89 & 2776,84 & 2812,79 & 2848,74 \\
\hline
\end{tabular}

Keterangan : Berdasarkan perhitungan Tabel 1 dan 2. 


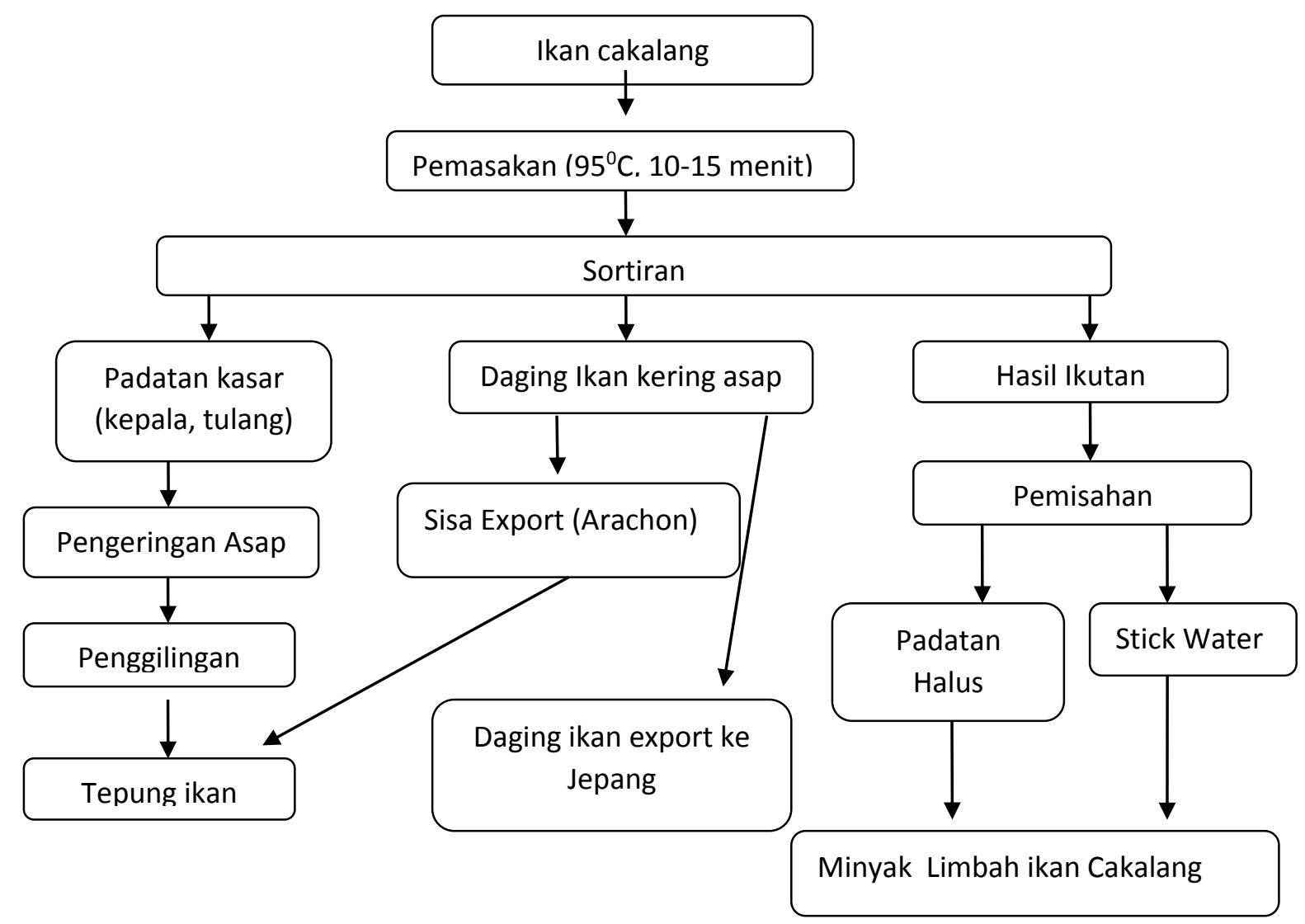

Gambar1. Skema Proses Pembuatan Minyak Limbah Ikan Cakalang (Katsuwonus pelamis L) Pembuatan Minyak Ikan di PT Nichindo Manado Suisan,Amurang Minahasa Selatan Privinsi Sulawesi Utara (2011).

Variabel yang diamati dalam penelitian meliputi :

1. Berat telur (North, 1984)

Berat telur merupakan perbandingan antara jumlah berat telur yang dihasilkan (g) dengan jumlah telur yang dihasilkan (butir) atau dengan rumus sebagai berikut:

$$
B \mathrm{~T}=\frac{\text { Jumlah berat telur yang dihasilkan }(\mathrm{g})}{\text { Jumlah telur yang dihasilkan (butir) }}
$$

2. Berat kuning telur (g)

Berat kunig telur diukur dengan cara menimbang setiap kuning telur
(Stadelman dan Cotterill, 1994). Pengukurannya dilakukan dengan melakukan penimbangan berat kuning telur (g) setelah dipisahkan dari putih telur.

3. Warna kuning telur (North dan Bell, 1992)

Warna kuning telur diperoleh dengan cara membandingkan warna kuning telur dengan Roche Yolk Colour Fan pada skala 1-15. 


\section{HASIL DAN PEMBAHASAN}

\section{Pengaruh Perlakuan Terhadap Berat Kuning Telur}

Pengaruh penggunaan minyak limbah ikan cakalang (katsuwonus pelamis $L)$ terhadap berat telur, berat kuning telur dan warna kuning telur dapat dilihat pada Tabel 4. Berdasarkan data pada Tabel 4 dapat diketahui bahwa kisaran berat telur yang diperoleh dari perlakuan R0, R1, R2, $\mathrm{R} 3$ dan R4 secara berurutan yaitu 55,66 ; 57,$22 ; 56,18 ; 56,21 ; 56,46$ gram/butir. Untuk mengetahui pengaruh perlakuan dilakukan analisis sidik ragam.

Hasil analisis sidik ragam menunjukkan bahwa pengaruh penggunaan minyak limbah ikan cakalang dalam ransum pada level $1 \%$ - $4 \%$ tidak memberikan pengaruh yang nyata $(\mathrm{P}>$ $0,05)$ terhadap berat telur ayam ras pertelur. Artinya pengunaan minyak limbah ikan cakalang dalam ransum pada level 1\% - 4\% belum memberikan perbedaan terhadap berat telur. Hal ini disebabkan karena adanya keseimbangan pada zat makanan dalam ransum pada masing - masing perlakuan, sehingga perlakuan ransum tidak mempengaruhi berat telur.

Suprapti (2002) menyatakan bahwa berat telur ditentukan oleh beberapa hal, antara lain oleh faktor keturunan, ransum, sistem pemeliharaan, iklim, air minum, dan umur ayam. Dalam penelitian ini dapat disimpulkan beberpa faktor yang mempengaruhi berat telur, antara lain, ransum yang dikonsumsi ternak dari perlakuan R0, R1, R2, R3 dan R4 hampir sama, hanya yang membededakan pada perlakuan R1 - R4 menggunakan ransum dengan penambahan $1 \%-4 \%$ minyak limbah ikan cakalang. Selain ransum, sistem pemeliharaan, iklim, air minum dan umur ayam yang digunakan dalam penelitian pada perlakuan R0 - R4 sama.

Tabel 4. Pengaruh Penggunaan Minyak Limbah Ikan Cakalang Terhadap Berat Telur (gram/butir), Berat Kuning Telur (gram/butir), Warna Kuning Telur.

\begin{tabular}{cccc}
\hline \multirow{2}{*}{ Perlakuan } & \multicolumn{3}{c}{ Variabel } \\
\cline { 2 - 4 } & Berat Telur $($ gr $)$ & $\begin{array}{c}\text { Berat Kuning Telur } \\
(\mathrm{gr})\end{array}$ & $\begin{array}{c}\text { Warna Kuning } \\
\text { Telur }\end{array}$ \\
\hline R0 & $55,66 \pm 0,91$ & $14,27 \pm 0,84$ & $8,03 \pm 0,52$ \\
R1 & $57,22 \pm 0,72$ & $14,76 \pm 0,50$ & $8,07 \pm 0,44$ \\
R2 & $56,18 \pm 0,45$ & $14,48 \pm 0,64$ & $8,13 \pm 0,21$ \\
R3 & $56,21 \pm 0,70$ & $14,56 \pm 0,44$ & $8,12 \pm 0,36$ \\
R4 & $56,46 \pm 0,74$ & $14,61 \pm 0,65$ & $8,12 \pm 0,34$ \\
\hline
\end{tabular}

Keterangan: Berat Telur, Berat Kuning Telur dan Warna Kuning Telur tidak berbeda nyata $(\mathrm{P}>0,05)$ 
Yuwono et al. (2006) menyebutkan bahwa bobot telur dipengaruhi oleh kualitas bibit (genetik) dan kualitas ransum yang diberikan, disamping faktor-faktor lainnya. Latifah (2007) menyatakan bahwa besar kecilnya ukuran telur unggas sangat dipengaruhi oleh kandungan protein dan asam-asam amino dalam pakan. North dan Bell (1992) menyatakan, bahwa telur dihasilkan dari induk ayam yang baru bertelur atau induk muda lebih kecil dibandingkan dengan telur yang dihasilkan dari induk yang lebih tua.

\section{Pengaruh Perlakuan Terhadap Berat}

\section{Kuning Telur}

Berdasarkan data pada Tabel 4 kisaran berat kuning telur untuk masingmasing perlakuan R0, R1, R2, R3, dan R4 secara berurutan yaitu 14,$27 ; 14,76 ; 14,48$; 14,56; dan 14,61 gram/butir. Untuk mengetahui pengaruh perlakuan dilakukan analisis sidik ragam.

Hasil analisis sidik ragam menyatakan bahwa pengaruh penggunaan minyak limbah ikan cakalang dalam ransum pada level $1 \%$ - $4 \%$ tidak memberikan pengaruh yang nyata $(\mathrm{P}>0,05)$ terhadap berat kuning telur ayam ras petelur. Artinya penggunaan minyak limbah ikan cakalang dalam ransum pada level $1 \%$ - $4 \%$ belum memberikan perbedaan terhadap berat kuning telur.
Menurut Agro et al. (2013), faktor yang mempengaruhi berat kuning telur adalah kandungan lemak dan protein dalam telur. Pada penelitian ini penggunaan limbah minyak ikan yang ditambahkan dalam ransum belum memberikan perbedaan yang nyata karena ransum yang dikonsumsi ternak sama dan komposisi protein dan lemak hampir sama.

Tugiyanti dan Iriyanti (2012) menyatakan bahwa berat kuning telur dipengaruhi oleh perkembangan ovarium, berat badan ayam, umur saat mencapai dewasa kelamin, kualitas dan kuantitas pakan, penyakit, lingkungan dan konsumsi pakan. Yuwanta (2010), proses pembentukan kuning telur menghasilkan berat kuning telur yang berbeda-beda tergantung dari kemampuan genetis masing-masing individu unggas tersebut. Agro et al. (2013) menyatakan bahwa asam lemak yang banyak terdapat pada kuning telur adalah linoleat, oleat dan stearat yang berfungsi untuk peningkatan berat kuning telur.

\section{Pengaruh Perlakuan Terhadap Warna Kuning Telur}

Berdasarkan data pada Tabel 4 kisaran warna kuning telur untuk masingmasing perlakuan R0, R1, R2, R3, dan R4 secara berurutan yaitu 8,$03 ; 8,07 ; 8,13 ; 8,12$ dan 8,12 gram/butir. Untuk mengetahui 
pengaruh perlakuan dilakukan analisis sidik ragam.

Hasil analisis sidik ragam menyatakan bahwa pengaruh penggunaan minyak limbah ikan cakalang dalam ransum pada level $1 \%$ - $4 \%$ tidak memberikan pengaruh yang nyata $(\mathrm{P}>0,05)$ terhadap warna kuning telur ayam ras petelur. Artinya penggunaan limbah minyak ikan cakalang dalam ransum pada level $1 \%$ - $4 \%$ belum memberikan perbedaan terhadap warna kuning telur.

Argo et al. (2013) menyatakan bahwa warna kuning telur dipengaruhi zatzat yang terkandung dalam pakan seperti xanthofil, beta karoten, klorofil, dan cytosan. Surai et al. (2000) mengemukakan bahwa jenis dan jumlah karotenoid yang ada dalam kuning telur tergantung pada jumlahnya dalam pakan yang dikonsumsi ayam. Karotenoid memberikan warna kuning pada kuning telur. Menurut Winarno (1993), karotenoid merupakan senyawa fat-soluble yang menyediakan warna merah dan orange pada tanaman, algae dan ikan. Karotenoid dibagi menjadi dua yaitu $\beta$-karoten dan xantofil. Warna kuning pada telur ayam sebagian besar disebabkan oleh zat warna yang disebut kriptoxantin, sejenis xantofil. Pada limbah minyak ikan yang digunakan pada penelitian ini karotenoid berasal dari ikan cakalang yang terdapat pada bagian daging yang berwarna pink.

\section{KESIMPULAN}

Berdasarkan hasil pembahasan diatas, maka dalam penelitian ini dapat disimpulkan bahwa penggunaan limbah minyak ikan dalam ransum ayam ras petelur sebanyak $1 \%$ - 4\% memberikan pengaruh yang sama terhadap kualitas telur.

\section{SARAN}

Penulis merekomendasikan untuk minyak limbah ikan cakalang (MLIC) yang digunakan harus diperhatikan kualitas dari pengolahan dan penyimpanan MLIC yang digunakan, karena MLIC sangat mudah terkontaminasi dengan udara dan cahaya, selain terkontaminasi hal tersebut dapat menyebabkan menurunya kualitas minyak MLIC juga mengakibatkan bau tengik pada MLIC.

\section{DAFTAR PUSTAKA}

Argo, L. B., Tristiarti dan I. Mangisah. 2013. Kualitas ayam arab petelur fase I dengan berbagai level Azolla microphylla. Animal Agricultural Journal. 2(1): 445-447.

Carrillo-Domínguez, S., M. E. CarrancoJauregui, R. M. Castillo-Domínguez, M. I. Castro-González, E. AvilaGonzález, and F. Pérez-Gil. 2005. Cholesterol and n-3 and n- 6 fatty acid content in eggs from laying hens fed 
with red crab meal (Pleuroncodes planipes). Poult. Sci. 84:167-17.

Gonzales-Esquerra R, Leeson S .2000. Effect of feeding hens regular or deodorized menhaden oil on production parameters, yolk fatty acid profile, and sensory quality of eggs. Poult Sci. 2000;79:1597-1602.

Hagris, P. S. dan M. E. Van Elswyk. 1991. Manipulation the fatty acids composition of poultry meat and eggs for the healt couscious consumer. World's Poulrty Sci Journal. 49 : 251264.

Iriyanti, N., M. Mufti dan T. Widiyastuti. 2007. Manipulasi pakan dengan imunostimulan probiotik dan prebiotik terhadap tampilan sistem immunologik berdasarkan profil darah dan mikroba saluran pencernaan ayam petelur, Laporan Penelitian DIPA Program Pascasarjana Fakultas Peternakan, Universitas Jenderal Soedirman, Purwokerto.

Latifah, R. 2007. The Increasing Of Afkir Duck's Egg Quality Whit Pregnant Mare's Serum Gonadotropin (Pmsg) Hormones. The way to increase of layer duck. 4:1-8.

Leke J. R, Vonny Rawung, J. Laihad, W. Utiah, J. S. Mandey. 2015. Penampilan produksi ayam kampung yang diberi ransum mengandung minyak ikan. Prosiding Seminar Nasional Peternakan Berkelanjutan. Unpad Bandung. Halaman 27-31. http://peternakan.unpad.ac.id

Milinsk, M.C., A.E. Murakami, S.T.M. Gomes, M. Matsushita, N.E. Souza. 2003. Fatty acid profile of egg yolk lipids from hens fed diets rich in n-3 fatty acids. Food Chem 83:287-292
National Research Council. 1994. Nutrient Requirements of Poultry. $9^{\text {th }}$ ed. National Academy Pr., Washington DC.

North, M. D. 1984. Commercial Chicken Production Manual. $2^{\text {nd }}$ Edition. The Avi Publishing Co., connecticub. 358366; 374-382; 416-489,493 ; 566-578

North, M. O. dan D. D. Bell. 1992. Commercial Chicken Production Manual. $4^{\text {th }}$ Edition. An AVI Book Published by Van Nostrand Reinhold, New York. Opena, R. T., Van Der Vossen. 1997. Lycopension Esculentum Mill. Dalam Siemonsma dan K.Piluek (eds) Plant Resources Of South East Asia. Puddock Scientific Publisher Waginingen Netherlands. Pp 199-205.

Permana, S., Bambang Pramono, Suhermiyati. 2003. Efek konsentrasi Kromium $(\mathrm{Cr} 3+)$ dan salinitas berbeda terhadap efisiensi pemanfaatan pakan untuk pertumbuhan ikan nila. Universitas Diponegoro, Semarang.

Stadelman and Cotteriil. 1994. Egg Science and Technology. Fourth edition. Food Products Press. United State America.

Steel, R.G.D. dan J.H Torrie, 1995. Prinsip dan Prosedur Statistika (Suatu Pendekatan Giometrik). PT. Gramedia Pustaka Utama. Jakarta. Hal: 48-233.

Suprapti, M. Lies. 2002. Pengawetan Telur. Yogyakarta : Kanisius.

Surai, P.F., R.M. McDevitt, B.K. Speake and N.H.C. Sparks 2000. Carotenoid distribution in issues of the laying hen depending on their dietary supplementation. Proc. Nurt. Soc. 58: 30A.

Tugiyanti, E. dan N. Iriyanti. 2012. Kualitas eksternal telur ayam petelur 
yang mendapat ransum dengan penambahan tepung ikan fermentasi menggunakan isolat prosedur antihistamin. Jurnal Aplikasi Teknologi Pangan. Vol. 1 No. 2. http://journal.ift.or.id/files/E.\%20Tugi yanti12-4447.pdf

Van Elswyk, M.E., B.M. Hargis, J.D. Williams, P.S. Hargis. 1994. Dietary menhaden oil contributes to hepatic lipidosis in laying hens. Poultry Sci. 73:653-662.
Winarno, F.G. 1993. Gizi, Teknologi, dan Konsumen. PT Gramedia Pustaka Utama. Jakarta

Yuwanta, T. 2010. Telur Dan Kualitas Telur. Gadjah Mada University Press. Yogyakarta.

Yuwono, D. M., Subiharta, Hermawan, Hartono. 2006. Produktivitas Itik Tegal di Sentra Pengembangan pada Pemeliharaan Intensif. Balai pengkajian Teknologi Pertanian Jawa Tengah. Unggaran. 